\title{
A CHINA E OS ACORDOS DE SWAP CAMBIAL COM ARGENTINA, BRASIL, CHILE E SURINAME
}

\author{
Ana Tereza Lopes Marra de Sousa'
}

William Daldegan²

Os acordos bilaterais de swap cambial ganharam grande importância devido à crise de 2008, e a China tem sido protagonista nesse movimento. Argentina, Brasil, Chile e Suriname individualmente e em momentos distintos estabeleceram tal tipo de tratativa com os chineses. Contudo, até agosto de 2020, apenas a Argentina, desses países, havia acionado o acordo. Neste trabalho, questionamos quais aspectos explicam a utilização ou não desses acordos com a China. Por meio de levantamento de dados primários e revisão bibliográfica, este estudo afirma que os acordos de swap estabelecidos com a China são importantes como fontes de liquidez em momentos de vulnerabilidade externa para os países latino-americanos; todavia, seu uso é limitado devido à baixa conversibilidade externa do renminbi (RMB).

Palavras-chave: acordos bilaterais de swap; China; Brasil; Argentina; Suriname.

\section{CHINA AND THE SWAP AGREEMENTS WITH ARGENTINA, BRAZIL, CHILE AND SURINAME}

\begin{abstract}
Bilateral swap agreements gained great importance due to the 2008 crisis and China has been a protagonist in this movement. Argentina, Brazil, Chile and Suriname individually and at different times established such a deal with the Chinese. However, until August 2020, only Argentina, of those countries, had activated the agreement. In this paper, we question which aspects explain the use or not of these agreements with China. Through primary data gathering and bibliographic review, this study states that the swap agreements established with China are important as sources of liquidity in times of external vulnerability for Latin American countries. However, its use is limited due to low convertibility of the Renminbi (RMB).
\end{abstract}

Keywords: Bilateral Swap Agreements; China; Brazil; Argentina; Suriname.

\section{CHINA Y LOS ACUERDOS DE SWAP CON ARGENTINA, BRASIL, CHILE Y SURINAM}

Los acuerdos bilaterales de swap cobraron gran importancia debido a la crisis de 2008 y China ha sido protagonista de este movimiento. Argentina, Brasil, Chile y Surinam, individualmente y en diferentes momentos, establecieron tal trato con los chinos. Sin embargo, hasta agosto de 2020, solo Argentina, de esos países, había activado el acuerdo. En este trabajo nos preguntamos qué aspectos explican el uso o no de estos acuerdos con China. Através de un relevamiento de datos

\footnotetext{
1. Professora adjunta do bacharelado em ciências e humanidade $(B C H)$, do bacharelado em relações internacionais (BRI) e do Programa de Pós-graduação em Relações Internacionais (PRI) da Universidade Federal do ABC (UFABC); e doutora em relações internacionais pela San Tiago Dantas, Universidade Estadual Paulista (Unesp) Universidade Estadual de Campinas (Unicamp) e Pontifícia Universidade Católica de São Paulo (PUC-SP). Orcid: <https://orcid.org/0000-0002-7580-4797>.

2. Professor adjunto do Instituto de Filosofia, Sociologia e Política da Universidade Federal de Pelotas (UFPel); e doutor em relações internacionais pela San Tiago Dantas, Unesp, Unicamp e PUC-SP.

Orcid: <https://orcid.org/ 0000-0001-5806-0557>
} 
primarios y una revisión bibliográfica, este estudio establece que los acuerdos de swap establecidos con China son importantes como fuentes de liquidez en tiempos de vulnerabilidad externa para los países latinoamericanos, sin embargo, su uso es limitado debido a la baja convertibilidad del renminbi (RMB).

Palabras clave: contratos bilaterales de swap; China; Brasil; Argentina; Surinam.

JEL: F30.

DOI: http://dx.doi.org/10.38116/rtm24art9

Data de envio do artigo: 31/8/2020. Data de aceite: 26/9/2020.

\section{INTRODUÇÃO}

No século XXI, os acordos bilaterais de swap (bilateral swap agreements - BSAs) cambial ganharam grande importância e volume a partir da crise de 2008. A China protagonizou esse movimento celebrando com quarenta países acordos que totalizaram, em 2020, 4 trilhōes de yuans. Na América Latina, Argentina, Brasil, Chile e Suriname individualmente se tornaram contrapartes nesses acordos. Em 2014, a Argentina tornou-se o primeiro país da região a acionar esse tipo de tratativa com a China. Os demais, à exceção do Brasil, mantêm vigentes os acordos sem ainda tê-los acionado.

Por meio de acordos de swap cambial, uma autoridade monetária se compromete a trocar a moeda nacional, por ela emitida, por outra moeda, também emitida e avalizada por outra autoridade monetária nacional, assim como garante sua recompra na forma preestabelecida em um determinado prazo e taxa. Os bancos centrais geralmente usam esse tipo de acordo em momentos de vulnerabilidade econômica, visando aumentar suas reservas em moeda estrangeira, obter recursos para emprestar aos seus bancos comerciais e ampliar a liquidez nos mercados. Devido às funçóes que os swaps cumprem, é esperado que países que emitem moedas de grande uso internacional sejam suas principais contrapartes, pois são eles que estão em melhores condiçôes de oferecer moedas que provêm liquidez em momentos de instabilidade.

Desde a crise de 2008, contudo, nenhum país criou tantos acordos de swap quanto a China. Tal fato chama atenção, pois: i) o renminbi (RMB) não é uma moeda de fácil conversibilidade externa, o que limita o seu uso nos mercados internacionais; e ii) os acordos chineses, diferentemente do que ocorre em grande parte dos celebrados por outros países, náo ficaram limitados ao contexto de crise, o que evidencia que possuem objetivos além dos tradicionalmente visados nesse tipo de tratativa.

Em um contexto de aumento da presença comercial e dos investimentos da China na América Latina, os acordos de swap representam um aprofundamento das relaçóes financeiras e monetárias. Todavia, apenas a tratativa celebrada com 
a Argentina foi acionada. Questiona-se: quais aspectos explicam a utilização ou não desses acordos com a China? Por que apenas a Argentina os acionou? Embora vários trabalhos tenham sido produzidos ao longo dos últimos anos sobre os swaps cambiais estabelecidos pela China, poucas pesquisas abordam casos que envolvem países latino-americanos. Há estudos que indicam que a não utilização dos acordos de swap pode significar que há dificuldades para o exercício da influência financeira e monetária internacional da China (McDowell, 2019). Seria esse o caso na América Latina?

$\mathrm{O}$ argumento desenvolvido no texto, a partir da análise dos casos, é o de que a baixa conversibilidade externa do RMB, bem como a inércia existente no Sistema Monetário Internacional (SMI), que favorece o uso do dólar, limitou a utilização dos acordos de swap pelos países da regiáo com a China. O acionamento do acordo pela Argentina teve como finalidade a obtenção dos recursos em RMB para acessar dólares nos mercados externos, a fim de lidar com uma vulnerabilidade de seu balanço de pagamentos. Sendo assim, nos países em que não houve grandes problemas de restriçấo externa, os acordos não foram acionados. Concluiu-se que os acordos de swap mostram limites se pensados enquanto estratégia direta para a internacionalização do RMB, ou mesmo como meio de substituir uma terceira moeda por moedas locais para o comércio e investimentos. Contudo, a utilização do acordo pela Argentina e a prorrogaçáo/renovação do acordo por Chile, Suriname e Argentina mostram que as tratativas podem prosperar como forma alternativa aos tradicionais emprestadores internacionais.

Para o exame das questóes levantadas, este trabalho adota a revisão bibliográfica somada ao levantamento de dados primários. O esforço de análise parte da comparação dos casos para tecer suas consideraçóes. Além desta introdução e das consideraçóes finais, o texto é dividido como segue. A segunda seção apresenta a noção de financial statecraft, a qual considera os BSAs um de seus instrumentos; o panorama geral acerca do estabelecimento de acordos de swap pós-crise de 2008 e suas singularidades a partir daqueles que os patrocinam será abordado na terceira. Na quarta seção, analisamos a China como provedora desses acordos, seus objetivos e dificuldades. Na quinta, exibimos a análise dos acordos firmados com Argentina, Brasil, Chile e Suriname e sua importância para cada um desses.

\section{A NOÇÃO DE FINANCIAL STATECRAFT}

Vários autores têm considerado os BSAs estabelecidos pela China como parte de um emergente financial statecraft do país (McDowell, 2019; Cohen, 2017). De acordo com Armijo e Katada (2015, p. 2, traduçáo nossa), financial statecraft pode ser definido como "o uso intencional, por governos nacionais, de capacidades 
financeiras ou monetárias domésticas ou internacionais para o propósito de atingir objetivos de política externa, tanto políticos como econômicos e financeiros". Como argumenta Drezner (2009), é comum que países que concentram muitos recursos passem a utilizá-los tanto como forma de resistir à pressão externa quanto como modo de pressionar outros países a realizarem seus objetivos.

Tradicionalmente, a literatura sobre financial statecraft possui um viés voltado à análise da atuação das grandes potências, uma vez que são elas que têm os recursos necessários para realizar tal tipo de ação. Isso tem feito com que muitos estudos sobre o assunto foquem alguns poucos tipos de uso do financial statecraft, sendo o mais comum a imposição de sanções (Armijo e Katada, 2015; Roberts, Armijo e Katada, 2018). Contudo, mudanças na distribuição de poder nas últimas décadas com a ascensão de países do sul global, em especial a China, têm permitido a eles a operação do financial statecraft próprio.

A China é o país em desenvolvimento que possui uma das melhores situaçóes considerando o acúmulo de recursos nas últimas décadas. Dados do Fundo Monetário Internacional (FMI), ${ }^{3}$ considerando os superavit acumulados nas transaçôes correntes entre 2012 e 2018 , colocam a China como o terceiro país com maior saldo, sendo que as reservas chinesas são as mais volumosas do mundo. Tais recursos têm possibilitado ao país operar internacionalmente o financial statecraft. Adicionalmente, a melhor situação chinesa, em comparação às economias centrais, durante a crise de 2008, bem como sua importância para a recuperação da economia mundial, a tornou parceira financeira para vários países, impulsionando o seu financial statecraft. A América Latina pode ser um exemplo disso.

Dados compilados pelo World Integrated Trade Solution (Wits) ${ }^{4}$ apontam que, enquanto em 2000 a China representava apenas 1,90\% das exportaçóes da América Latina e do Caribe, em 2018 foi responsável por 12,33\%. Enquanto em 2000 sua participaçáo nas importaçóes era de 2,29\%, em 2018 se expandiu para $18,94 \% .{ }^{5}$ Em termos de investimento, diversas publicaçóes, como as de Blanchard (2016) e Rodrigues e Hendler (2018), assinalam a chegada dos fluxos chineses à América Latina em diferentes áreas, principalmente após a crise de 2008, com destaque para os setores energético, mineral, de infraestrutura, serviços financeiros, manufatura e commodities. Já no caso dos financiamentos, o banco de dados criado pelo The Dialogue mostra que, de 2005 a 2019, cerca de US\$ 137,6 bilhóes foram emprestados a países da regiáo para projetos

3. Disponivel em: <https://bit.ly/20aeY9q>.

4. 0 Wits é um sistema do Banco Mundial em que é possível gerar estatísticas e gráficos diversos de comércio exterior. Disponivel em: <https://wits. worldbank.org/countrystats.aspx?lang=en>.

5. Disponível em: <https://wits.worldbank.org/>. 
diversos (Gallagher e Myers, 2020). Desse modo, não só comercialmente, mas também na esfera financeira, em termos de origem de investimentos diretos e de financiamentos e empréstimos, a China tem aprofundado sua presença na América Latina.

Armijo e Katada (2015) propóem três dimensões de análise do financial statecraft, baseadas: i) no motivo; ii) no alvo; e iii) no tipo. Sobre o motivo, os autores assinalam que os governos dos Estados podem ser motivados por objetivos políticos que são defensivos ou ofensivos ao operarem o financial statecraft. Os defensivos têm como base a finalidade de proteção interna e miram açóes que tendem a preservar o status quo doméstico. Seriam exemplos de ações de financial statecraft baseadas em motivos defensivos: a nacionalização de investimentos estrangeiros; a decretação de moratória de dívidas externas; o estabelecimento de controles de capital; a busca pela diversificação de fontes de capital no exterior; a promoção ao acúmulo de reservas internacionais e sua diversificação; e, entre outros, a participação mais ativa na governança monetária e financeira internacional.

Já os motivos ofensivos teriam como finalidade a alteração do status quo internacional com base no exercício da pressão sobre outros países e o próprio sistema para que se estabeleçam determinados cursos de ação. Seriam exemplos de iniciativas de financial statecraft com motivos ofensivos: o estabelecimento de sançôes ou subornos; a manipulação do câmbio visando obrigar outros países a ajustarem o balanço de pagamentos; a promoção do mercado financeiro nacional como fonte de influência global; o impulso da própria moeda como meio de reserva e troca para as transaçóes internacionais; e, entre outros, a constituição de órgãos globais de governança em que seja dado ao país poder desproporcional maior em relação aos outros membros (Armijo e Katada, 2015).

Já no que se refere ao alvo do financial statecraft, Armijo e Katada (2015) o distinguem como sendo bilateral ou sistêmico. No bilateral, o objeto da ação de financial statecraft é um Estado específico, do qual se busca determinado posicionamento ou ação, enquanto no sistêmico o foco é se defender ou exercer influência sobre o mercado global, seus regimes, regras, processos e instituiçóes. Ressalta-se que, seja para o alvo bilateral, seja para o alvo sistêmico, tanto açóes defensivas como ofensivas podem ser utilizadas visando atingir o objetivo. Tal fato depende, como mencionado, da motivação para operar o financial statecraft - se é a manutenção ou a alteração do status quo da relação bilateral ou das condiçôes sistêmicas.

Quanto ao tipo de financial statecraft, Armijo e Katada (2015) assinalam que pode ser financeiro ou monetário. O financeiro envolve todos os aspectos que se relacionam aos fluxos de investimento e crédito internacional, como a ajuda 
externa, a regulação de capital e empréstimos. Já o monetário refere-se ao uso do valor da moeda, suas taxas de câmbio, seu regime, ou a formas de reserva como meio para atingir um objetivo de política externa.

Armijo e Katada (2015) ressaltam, ainda, que, apesar da proposição das diferentes dimensóes e maneiras de operar o financial statecraft assinaladas, é comum que os países mesclem os seus meios de atuação, de modo que um mesmo ator pode realizar ações que podem ser interpretadas dentro de mais de uma das categorias de atuação citadas.

Os BSAs cambiais celebrados pela China podem ser vistos como uma expressão do financial statecraft do país (McDowell, 2019; Cohen, 2017) - do uso da força financeira e monetária do Estado chinês com a finalidade de alcançar objetivos de política externa. Destais (2016), Yelery (2016) e Ryan (2017) afirmam que os objetivos da China em firmar os acordos são variados e incluem desde a busca por impulsionar uma diversificação do SMI, agindo para internacionalizar o $\mathrm{RMB}$, até o apoio aos investimentos e ao comércio exterior, iniciativas específicas de política externa - como a Iniciativa da Rota e do Cinturão (Belt and Road Initiative - BRI) - e o provimento de maior segurança e confiança para as relaçóes econômicas bilaterais.

\section{PANORAMA GERAL DOS ACORDOS DE SWAP DESDE A CRISE DE 2008}

Tooze (2018) coloca os Estados Unidos como o país que, em termos de valores, por meio do Sistema da Reserva Federal (Federal Reserve System - FED), que atua como banco central americano, operou o maior volume de acordos de swap no cenário da crise de 2008: US\$ 4,5 trilhóes. Devido à importância do dólar enquanto principal moeda de reserva, unidade de conta e meio de pagamento global, no contexto da falta de liquidez que marcou a crise de 2008, os swaps foram vistos pelo FED como uma forma de evitar o colapso dos mercados e garantir um mínimo de atendimento à demanda internacional por dólares (Tooze, 2018).

De fato, é esperado que autoridades monetárias encarregadas de gerir moedas com funçôes internacionais, como o FED, responsável pelo dólar, e o Banco Central Europeu (BCE), responsável pelo euro, tenham papel de destaque na celebraçáo de BSAs, uma vez que podem oferecer grande liquidez em momentos de crise. Foi esse o cenário que emergiu às vésperas de 2008, quando a incerteza com relação à real situação de risco das instituições financeiras bancárias e não bancárias começou a drenar a liquidez dos mercados. Naquele momento, como não se sabia o nível da exposição dessas instituições a ativos "tóxicos", os empréstimos para acessar moedas estrangeiras começaram a ficar mais caros e difíceis, gerando pressão nas reservas internacionais de alguns países que se viram na necessidade de socorrer os bancos domésticos. 
Foi visando resolver esses problemas de liquidez que o FED iniciou, no final de 2007, a abertura e a expansão de uma série de linhas de swap. De acordo com o FED (tradução nossa), o objetivo de tais tratativas era "ajudar a promover a disseminação eficiente da liquidez quando os mercados interbancários sem garantia estâo sob tensão". ${ }^{6}$ Os acordos voltaram-se majoritariamente aos países desenvolvidos, já que eles foram vistos como mercados com maior potencial de "contaminar" a economia americana e mundial em caso de forte desestabilização (Steil, 2019).

Os primeiros swaps foram processados em dezembro de 2007 com o BCE e o Banco Nacional da Suíça. No entanto, após a quebra do Lehman Brothers, em setembro de 2008, em um cenário de quase paralisação das atividades interbancárias, os acordos se expandiram: mais recursos foram aportados nas linhas já abertas com o BCE e a Suíça; e celebraram-se novos acordos com Canadá, Reino Unido, Japão, Austrália, Dinamarca, Noruega, Suécia e Nova Zelândia. Além disso, os bancos europeus processaram swaps entre si: o BCE celebrou acordos com Suécia, Suíça, Dinamarca e Reino Unido. Em 2011, estabeleceu-se, ainda, visando prevenir problemas de liquidez, uma rede de swaps entre autoridades monetárias de Canadá, Inglaterra, Japão, Estados Unidos, Suíça e União Europeia - em 2013, porém, decidiu-se por manter tal rede permanentemente ativa, de forma a garantir o acesso facilitado dos países à moeda estrangeira no caso de ocorrência de crises (Steil, 2019).

Com os países em desenvolvimento, poucas linhas de swap foram realizadas. Foram escolhidas apenas as autoridades monetárias de mercados considerados como fontes potenciais de "contaminaçáa" à economia regional ou global. Em outubro de 2008, o FED estendeu linhas a Coreia do Sul, Singapura e a dois países da América Latina, México e Brasil, percebidos como os países na regiâa com maior risco de os sistemas bancários nacionais estarem comprometidos com os ativos "tóxicos" da crise. Autoridades monetárias europeias, por sua vez, realizaram acordos com Hungria, Polônia, Letônia, Estônia e Islândia (Steil, 2019).

A partir de 2010 e 2011, grande parte das linhas de swap citadas foi desativada, já que os problemas de liquidez provocados pelo período mais agudo da crise haviam passado. Como citado, permaneceu ativa somente a rede de swaps acordada entre os países desenvolvidos em 2011 e transformada em um acordo por tempo indeterminado em 2013. Aos países em desenvolvimento, não foram mantidas as tratativas (Steil, 2019). Em 2020, contudo, voltou-se a ter um maior volume desse tipo de acordo devido à pandemia de Covid-19.

6. Disponivel em: <http://bit.ly/2NAEcOx>. 
Com a decretação da pandemia em março de 2020, e diante do colapso dos mercados de petróleo, já prevendo os problemas de liquidez, além da utilização das linhas existentes com os países desenvolvidos, o FED celebrou novos acordos com nove autoridades monetárias: Austrália, Dinamarca, Coreia do Sul, Noruega, Nova Zelândia, Singapura, Suécia e, da América Latina, novamente Brasil e México. De acordo com o FED (tradução nossa),

essas facilidades, como aquelas já estabelecidas entre o Federal Reserve e outros bancos centrais, são projetadas para ajudar a diminuir as tensôes nos mercados globais de financiamento em dólares, mitigando, assim, os efeitos dessas tensōes na oferta de crédito para famílias e empresas, tanto no mercado interno quanto no exterior. ${ }^{7}$

Importante recordar que, para os países em desenvolvimento em especial, tais acordos oferecem a oportunidade de acessar dólares em momentos de restrição financeira sem precisar aderir a programas de ajuste, como acontece quando se utilizam recursos, por exemplo, do FMI. A citaçáo anterior, contudo, corrobora a ideia de que os recursos provenientes dos países desenvolvidos por meio de BSAs ficam restritos apenas a momentos de crise. Por tal razão, interpreta-se que esses swaps evidenciam, nessa situação específica, um uso defensivo do financial statecraft desses Estados, no qual a operação mira alvos bilaterais, mas, por meio deles, busca-se a garantia do status quo da contraparte não só da tratativa como do próprio sistema. Tais acordos podem ser vistos ainda como voltados para o financeiro mais do que o monetário, pois buscam preservar a fluidez dos fluxos de capitais.

\section{BSAs E A CHINA}

Os primeiros acordos de swap cambial firmados pela China ocorreram em 2000 com a constituição da Iniciativa Chiang Mai (Chiang Mai Initiative - CMI), estabelecida entre os países da Associação das Nações do Sudeste Asiático (Asean) com a China, o Japão e a Coreia do Sul. Tal acordo teve como objetivo a realizaçáo de BSAs entre cada um dos três países e deles com os da Asean, visando criar uma alternativa regional, ainda que vinculada ao FMI, para momentos de crise de liquidez. ${ }^{8} \mathrm{O}$ contexto que deu ensejo à criação da CMI foi a crise asiática que se iniciou em 1997. Tal crise mostrou as dificuldades dos países da regiáo de acessar recursos de maneira rápida e em condiçóes justas, levando-os a negociar o mecanismo regional de swaps como forma de lidar com os constrangimentos impostos pelo sistema financeiro internacional (Gowan, 2003). Nesse caso, interpreta-se que a motivação para tais swaps foi eminentemente defensiva, sistêmica e voltada para questôes financeiras - assegurar a liquidez.

7. Disponível em: <http://bit.ly/2Myolwi>.

8. Estabeleceu-se que, para acessar mais de $20 \%$ dos recursos a que os países tinham direito, seria necessário firmar um acordo prévio com o FMI. 
A crise de 2008 marcou um segundo momento em que a China firmou BSAs; os objetivos de tais tratativas, contudo, estenderam-se para além do provimento de recursos para momentos de crise. Os acordos que a China passou a celebrar desde então encontram como causa profunda uma nova percepção do país sobre o funcionamento do sistema financeiro e monetário internacional (Park, 2016). Sabe-se que, historicamente (desde o fim da Segunda Guerra Mundial), o sistema monetário é dominado pelo dólar, o que faz com que seu desenvolvimento dependa das decisões de política monetária dos Estados Unidos, dando a esse país um "privilégio exorbitante", que inclui fechar suas contas na própria moeda (Eichengreen, 2011). Mesmo que tal facilidade tenha ajudado a impulsionar o consumo estadunidense de bens e serviços chineses ao longo do tempo (o que foi importante para o desenvolvimento chinês), ${ }^{9}$ da perspectiva da China, a crise de 2008 marcou a crescente dificuldade de conciliação das demandas por estabilidade e crescimento globais com os interesses da política monetária dos Estados Unidos (Xiaochuan, 2009).

As açôes tomadas pelos Estados Unidos no cenário da crise de 2008, em especial a política monetária expansionista do quantitative easing implementada pelo FED, pelo potencial de desvalorizar o dólar, causar inflação e diminuir reservas internacionais, fizeram com que a China passasse a perceber as fragilidades do sistema monetário baseado no dólar como ameaças, em médio e longo prazo, ao seu desenvolvimento (Park, 2016), que necessita de um ambiente estável sob o qual o país possa planejar e conduzir suas reformas (Deng, 2008).

Os problemas de liquidez produzidos pela crise, contudo, intensificaram num primeiro momento a dependência do sistema financeiro, com base em Wall Street, e do sistema monetário com relação ao dólar e às políticas monetárias dos Estados Unidos. Os primeiros acordos de swap fechados pela China no cenário da crise contribuíram para contornar esse constrangimento, de modo a evitar a ocorrência de problemas de liquidez em parceiros, em especial na Ásia, que pudessem desestabilizar a economia chinesa. $\mathrm{O}$ primeiro acordo celebrado pelo Banco Popular da China (People's Bank of China - PBOC) ocorreu em 2008 com a Coreia do Sul, no valor de 360 bilhóes de yuans justamente com o objetivo de prover "a liquidez adequada ao sistema financeiro das duas maiores economias do leste asiático" (Zhiming e Xiaokun, 2008, tradução nossa). Ainda em 2008, foram estabelecidos BSAs com a autoridade monetária de Singapura e de Hong Kong também com a finalidade de prover liquidez de curto prazo. Todos esses acordos foram acionados pelas partes (McDowell, 2019).

9. Referindo ao cenário pré-crise de 2008, Ferguson e Schularik (2007) cunharam o termo Chimerica para encapsular a ideia de uma nova ordem econômica internacional baseada na simbiose entre as economias chinesa e americana, em que a China se destacaria pelo seu crescimento baseado nas exportações e os Estados Unidos, pelo consumo. 0 fato de os Estados Unidos não possuírem restrição externa, em função do uso do dólar enquanto meio de reserva global, foi um fator essencial para que o país pudesse assumir o papel de consumidor dos bens e serviços chineses. 
Em 2010, a CMI evoluiu para a constituição de uma nova rede de swaps regionais por meio da Iniciativa Chiang Mai de Multilateralização (Chiang Mai Initiative Multilateralization - CMIM), que substituiu a CMI e os swaps bilaterais que existiam entre os países da Asean e de China, Japão e Coreia do Sul. Apesar de nunca terem sido acionados, esses swaps representaram um avanço na institucionalidade regional asiática, visando ao oferecimento de recursos em momentos de crise de liquidez.

Como aponta Yelery (2016), uma das funçôes das tratativas realizadas pela China - ainda dentro da visão tradicional de usar swaps para situaçốes de crise - é contribuir para a proteção da própria economia em momentos de volatilidade global. Em especial, justifica-se a atenção dada até então pelos acordos aos países da Ásia, os quais teriam maior potencial de "contagiar" a economia chinesa, o que demonstra que, nessa altura, os acordos celebrados pela China ainda podem ser interpretados dentro de uma visão da utilização do financial statecraft - por meio dos swaps - de forma defensiva, mesclando ações bilaterais e sistêmicas, e voltadas às questóes financeiras (o oferecimento de liquidez).

Entretanto, além dessa função mais comum que os BSAs cumprem, a partir de 2009, a China passou também a celebrar tratativas visando a outros objetivos: a internacionalizaçáo do RMB; a defesa e a garantia do comércio exterior chinês; e o atendimento de outros objetivos específicos de política externa.

No que se pode considerar uma justificativa para a internacionalização do $\mathrm{RMB}$, em uma avaliação sobre o papel que deveria idealmente ser desempenhado por moedas de uso internacional, o então governador do PBOC, Zhou Xiaochuan, afirmou o seguinte.

Teoricamente, uma moeda internacional de reserva deveria primeiro ser ancorada a uma referência estável e emitida de acordo com uma estrutura clara de regras, assegurando, assim, oferta ordenada; segundo, sua oferta deveria ser flexível o suficiente para permitir ajuste oportuno de acordo com a mudança da demanda; terceiro, esses ajustes deveriam estar desconectados das condiçôes econômicas e dos interesses soberanos de qualquer país (Xiaochuan, 2009, p. 1, tradução nossa).

Nada do que é pontuado por Zhou, contudo, podia ser aplicado ao papel que o dólar exercia (e ainda exerce) sobre o sistema monetário, motivo pelo qual as autoridades chinesas passaram a trabalhar com a ideia de que outras alternativas deveriam ser impulsionadas para dar mais diversidade monetária ao sistema, entre elas o RMB (Zhang e Tao, 2014).

Dentro desse quadro, a internacionalização da moeda chinesa foi processada como um fator que cumpriria múltiplos propósitos, desde impulsionar a continuidade das reformas financeiras domésticas chinesas que assegurariam maior inserção econômica internacional (Kroeber, 2013) até, sobretudo, 
ajudar o país a lidar com os constrangimentos externos impostos pela crise, e no médio e longo prazo produzir maior autonomia e poder para a China nas relações internacionais. Como afirma Strange (1994), o poder sobre a estrutura das finanças internacionais, que envolve a capacidade de criação de moeda e crédito, essenciais para o acesso e a distribuição dos recursos necessários ao desenvolvimento, é um aspecto essencial da economia política global. A China tornou-se em 2010 a segunda maior economia do mundo, ultrapassando o Japão. Em 2011, porém, segundo dados da Swift, ${ }^{10} \mathrm{o}$ RMB ocupava apenas a $17^{\mathrm{a}}$ posição como moeda mais utilizada para a realização de pagamentos, lugar inadequado considerando a importância econômica global do país.

Os BSAs, por sua vez, não foram os únicos instrumentos utilizados para a internacionalização do RMB. A partir de 2008, o governo chinês passou a incentivar um conjunto de diferentes açôes, das quais citam-se: a inclusão do RMB na cesta dos direitos especiais de saque (DES) do FMI; a criaçáo e posterior universalização de programas para a facilitação da liquidação do comércio e de investimentos externos em RMB; a expansão das clearings no exterior que podem operar RMB; a criaçáo do China International Payment System (Cips); entre outros (Sousa e Freitas, 2018).

No que diz respeito aos BSAs, Destais (2016, p. 2258, traduçấo nossa) aponta que "o objetivo chinês em explorar essa ferramenta é promover a internacionalização do RMB e, eventualmente, escapar da dominação do dólar americano". Os BSAs oferecem nesses casos a possibilidade de realizar fluxos financeiros e comerciais com a compensação das transaçóes em moedas nacionais dos países sem a necessidade do atrelamento ao dólar. A vantagem de utilização do acordo seria resguardar os fluxos comerciais e financeiros da volatilidade do dólar, e, em caso de dificuldades de acessar a moeda estrangeira, o comércio e os investimentos bilaterais não estariam paralisados, pois seria possível contar com as moedas locais.

A partir de 2009, com o acordo celebrado com a Malásia, vários BSAs fechados pela China passaram, assim, a ter também como foco a promoção do comércio e do investimento bilateral em RMB, sendo que a utilização dos recursos do acordo para momentos de crise de liquidez começou a desaparecer como opção de várias tratativas, como a celebrada com o Brasil em 2013 ou com o Chile em 2015. Desse modo, o apoio aos investimentos e, em especial, ao comércio exterior bilateral passou a ser um fator explicativo para os BSAs celebrados pela China, aspecto que, junto com o propósito de internacionalizar a moeda, difere os swaps chineses daqueles estabelecidos pelos países desenvolvidos.

10. Disponivel em: <http://bit.ly/3kxclFq>. 
É bom frisar que o comércio exterior tem um papel importante como fator de desenvolvimento para a China. Dados do Wits ${ }^{11}$ evidenciam que, entre 1970 e 2006, a exportaçáo de bens e serviços como porcentagem do produto interno bruto (PIB) foi crescente para o país (em 2006, atingiu o pico de pouco mais de 35\%). Dessa maneira, ao lado dos investimentos, as exportaçóes ajudaram a sustentar o processo de desenvolvimento chinês. Com a crise de 2008, contudo, o comércio exterior do país foi muito afetado, havendo redução das exportaçôes chinesas entre 2008 e 2009, ${ }^{12}$ motivo pelo qual os BSAs passaram a ser pensados, como indica Ryan (2017), para ajudar a reforçar e garantir o comércio da China com seus parceiros.

O fato de a China ter amplas relaçôes comerciais (desde 2012 é o país que possui a maior corrente de comércio do mundo) e ser uma importante parceira para muitos países - segundo Corrêa e Barbosa (2017), em 2015, era a primeira parceira comercial de 120 naçóes - abriu margem para a celebração de acordos no mundo todo, com destaque para os Estados em desenvolvimento. Como mostra o quadro 1, apesar de existirem BSAs da China com países desenvolvidos, a maioria deles foi firmada com o mundo em desenvolvimento, pois nele estáo as economias que possuem a maior suscetibilidade de precisar dos recursos. Tradicionalmente, em momentos de crise, esses países teriam que recorrer ao FMI e em troca aceitar programas de ajuste.

Outro motivo que também tem sido elencado como propulsor dos acordos de swap é o BRI. O BRI é considerado a principal ação de política externa do governo Xi Jinping. É um projeto focado no desenvolvimento de infraestrutura cujo objetivo é "prover a conectividade dos continentes asiático, europeu, africano e seus oceanos adjacentes" (tradução nossa). ${ }^{13}$ Contudo, países de outras regiôes também têm aderido à iniciativa em busca de recursos para o desenvolvimento de infraestrutura. Na América Latina, dezoito países se juntaram ao BRI, entre eles o Chile e o Suriname. Estima-se que países que fazem parte da iniciativa e que estão desenvolvendo projetos com a China, como é o caso do Paquistão, devido à construção do Corredor Econômico China-Paquistão (CEPC), tenham acordos de swap impulsionados como forma de ajudar a garantir o comércio e os investimentos bilaterais.

11. Disponível em: <https://wits. worldbank.org/>.

12. De acordo com dados do Trade Map, enquanto em 2008 as exportações chinesas contabilizaram US\$1.430.693.100, em 2009 diminuíram para US\$1.201.646.800. Disponível em: <https://www.trademap.org/Bilateral_TS.aspx>.

13. Disponível em: <http://bit.ly/3pW09nZ>. 


\section{QUADRO 1}

\section{BSAs estabelecidos pela China (2008-2020)}

\begin{tabular}{|c|c|c|c|}
\hline Região & Data do primeiro acordo & Parceiro & Valor (RMB) \\
\hline Ásia & 2008 & Coreia do Sul & 360 bilhões \\
\hline Ásia & 2008 & Malásia & 180 bilhões \\
\hline Ásia & 2008 & Singapura & 300 bilhões \\
\hline Ásia & 2009 & Hong Kong & 490 bilhões \\
\hline Europa & 2009 & Belarus & 20 bilhões \\
\hline América & 2009 & Argentina & 70 bilhões \\
\hline Europa & 2010 & Islândia & 3,5 bilhões \\
\hline Ásia/Oceania & 2010 & Indonésia & 100 bilhões \\
\hline Ásia & 2011 & Mongólia & 15 bilhões \\
\hline Ásia & 2011 & Cazaquistão & 7 bilhões \\
\hline Ásia & 2011 & Uzbequistão & 700 milhões \\
\hline Ásia & 2011 & Paquistão & 10 bilhões \\
\hline Ásia & 2011 & Tailândia & 70 bilhões \\
\hline Oceania & 2011 & Nova Zelândia & 25 bilhões \\
\hline Europa/Ásia & 2012 & Turquia & 10 bilhões \\
\hline Europa & 2012 & Ucrânia & 15 bilhões \\
\hline Ásia & 2012 & Emirados Árabes Unidos & 35 bilhões \\
\hline Oceania & 2012 & Austrália & 200 bilhões \\
\hline América & 2013 & Brasil & 190 bilhões \\
\hline Europa & 2013 & Reino Unido & 200 bilhões \\
\hline Europa & 2013 & Albânia & 2 bilhões \\
\hline Europa & 2013 & Hungria & 10 bilhões \\
\hline Europa & 2013 & União Europeia & 350 bilhões \\
\hline Europa & 2014 & Dinamarca & 150 bilhões \\
\hline Ásia & 2014 & Sri Lanka & 10 bilhões \\
\hline Europa/Ásia & 2014 & Rússia & 150 bilhões \\
\hline Ásia & 2014 & Qatar & 35 bilhões \\
\hline América & 2014 & Canadá & 200 bilhões \\
\hline Europa & 2014 & Suiç̧a & 150 bilhões \\
\hline Europa & 2015 & Armênia & 1 bilhão \\
\hline América & 2015 & Suriname & 1 bilhão \\
\hline África & 2015 & África do Sul & 30 bilhões \\
\hline América & 2015 & Chile & 22,8 bilhões \\
\hline Ásia & 2015 & Tajiquistão & 3,2 bilhões \\
\hline África & 2016 & Egito & 18 bilhões \\
\hline África & 2016 & Marrocos & 16 bilhões \\
\hline Europa & 2016 & Sérvia & 1,5 bilhão \\
\hline África & 2018 & Nigéria & 15 bilhões \\
\hline Ásia & 2018 & Japão & 30 bilhões \\
\hline África & 2020 & Zimbábue & 29 bilhões \\
\hline
\end{tabular}

Fonte: Destais (2016), Zhitao, Wenjie e Cheung (2016), Yelery (2016), République Française (2018), Kajimoto (2018) e Samaita (2020).

Elaboração dos autores. 
Desse modo, percebe-se que os swaps evoluíram na estratégia chinesa de uma forma de utilização do financial statecraft defensiva para uma forma ofensiva, que visa à internacionalização da moeda. Ela é operada de maneira bilateral, mas pretende atingir objetivos que são sistêmicos, como a construção de um SMI com maior participação do RMB. Tais BSAs estabelecidos pela China, além do aspecto financeiro (o oferecimento de liquidez para os países), miram também o monetário, uma vez que incentivam o uso da moeda chinesa como meio de troca e reserva. Desse modo, pode-se afirmar que os swaps chineses diferem substancialmente dos oferecidos pelos países desenvolvidos.

Entretanto, apesar de a China ter celebrado swaps com cerca de quarenta países, poucos deles foram efetivamente acionados. Como mencionado, os primeiros acordos voltados para resolver problemas de liquidez de curto prazo, ainda em 2008, com Coreia do Sul, Hong Kong e Singapura foram utilizados. Além desses, tem-se notícia apenas da utilização do acordo com o Paquistão em 2013, com a Argentina em 2014-2015 e com a Rússia em 2016 (McDowell, 2019). Em todos os três casos, os acordos foram acionados pelos países devido a problemas de restrição externa, de modo que os recursos não foram utilizados diretamente para o comércio e investimentos nem contribuíram para a internacionalização do RMB. Tal fato tem levado analistas a questionarem se a estratégia chinesa de swaps, visando a tais objetivos, estaria sendo bem-sucedida.

McDowell (2019) aponta a baixa internacionalizaçáo do RMB como um dos principais motivos que explicam a pouca utilização dos acordos de swap celebrados pela China. No que se refere a meio de reserva, apesar de países como Indonésia e Austrália e a Uniáo Europeia terem passado a acumular reservas em RMB, dados do $\mathrm{FMI}^{14}$ mostram que, no fim de 2019, apenas 1,96\% das reservas alocadas eram na moeda chinesa - atrás de dólar, euro, libra e yen. No que se refere à sua utilização enquanto meio de troca, estatísticas da Swift ${ }^{15}$ mostram que, em fevereiro de 2020, 2,11\% dos pagamentos operados pela plataforma foram em RMB, estando tal moeda apenas na quinta posição como a mais utilizada.

Um dos aspectos mais apontados pela literatura como explicativos para a baixa internacionalização da moeda chinesa é o relativo fechamento da conta capital e financeira da China, dado que o país ainda dificulta o acesso de entidades estrangeiras ao mercado chinês de RMB, bem como controla a quantidade de moeda nacional que disponibiliza no exterior (Park, 2016; Zhang e Tao, 2014). Tal fato torna a conversibilidade externa do RMB difícil de ser realizada, se comparada a outras moedas de uso internacional.

14. Disponivel em: <https://bit.ly/37Zlc1H>.

15. Disponivel em: <https://bit.ly/3kxclFq>. 
Outro elemento destacado para explicar a dificuldade de internacionalização de moedas, em que se pode incluir o RMB, é que existe uma inércia no SMI que tende a privilegiar o uso das divisas que já são as mais utilizadas, visando, assim, facilitar as trocas, a denominação e o acúmulo de reservas por meio de uma moeda comum (Eichengreen, 2011). Se não houver a existência de fortes incentivos para a mudança das moedas de uso internacional - o que geralmente ocorre apenas em ocasióes muito especiais, como guerras mundiais -, dificilmente moedas de uso mais corrente serão abandonadas a favor das que estáo em ascensão (op. cit.). Essas dificuldades fazem com que mesmo os países que possuem acordos de swap com a China prefiram manter suas transaçóes em moedas de maior liquidez. A experiência dos últimos anos mostra, assim, que somente em casos de dificuldade de acessar recursos em outras moedas, em especial em dólar, que os acordos de swap com a China são considerados uma opção de uso.

\section{ANÁLISE DOS CASOS}

Com base nas informaçôes das seções anteriores, os tópicos a seguir destacam os BSAs estabelecidos por cada um dos países - Argentina, Brasil, Chile e Suriname e a China, bem como são explorados os motivos para sua utilização ou não.

\subsection{Argentina}

China e Argentina estabeleceram relaçóes diplomáticas em 1972. Contudo, foi apenas na década de 2000 que as relaçôes econômicas se tornaram mais significativas, "quando a demanda chinesa criou um boom da soja nos Pampas, permitindo à Argentina se recuperar de sua pior crise econômica" (Stanley, 2019, p. 193, tradução nossa). Como mostra o gráfico 1, as relaçóes comerciais entre os países foram crescentes desde então, com a Argentina acumulando saldos positivos no comércio bilateral entre 2001 e 2007.

A partir de 2008, com as crescentes importaçóes de manufaturados diversos provenientes da China, o país ficou deficitário nas trocas bilaterais. Em contrapartida, a China gradualmente tornou-se mais importante para a economia argentina, chegando a se tornar, em 2020, no contexto da pandemia, o maior parceiro comercial argentino (Carmo, 2020).

Ao lado da intensificação das relaçóes econômicas, também a aproximação política entre os países se aprofundou. Em 2015, foi celebrada uma aliança estratégica, e em 2019 o presidente Alberto Fernández indicou a pretensão de aderir ao BRI. Em termos financeiros e de investimentos, a China tornou-se também uma importante parceira para a Argentina. Entre 2005 e 2019, segundo dados de Gallagher e Myers (2020), doze empréstimos totalizando US\$12,1 bilhôes foram fornecidos à Argentina, já Eleisegui (2019) destaca diferentes projetos de investimentos chineses em setores como mineração, transporte e energia. 


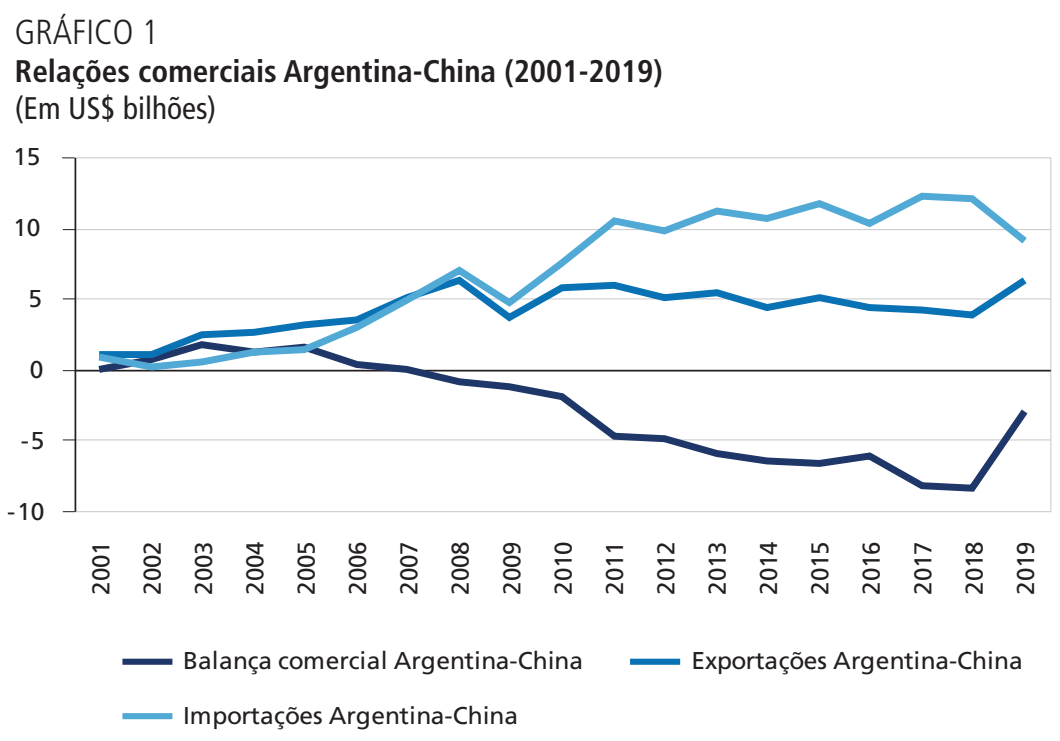

Fonte: Trade Map. Disponível em: <https://www.trademap.org/Bilateral_TS.aspx>.

Elaboração dos autores.

Foi nesse contexto de crescente aproximação que os países celebraram o primeiro acordo de swap em 2009. Com validade de três anos, prorrogável, o BSA teve como montante 70 bilhóes de yuans (cerca de US\$ 11 bilhóes) (BCRA, 2009), com a expectativa de que os valores pudessem auxiliar o pagamento das importaçóes chinesas pela Argentina. Esse acordo, porém, expirou em 2012, sem pedidos para renovação. Como assinalou o próprio Banco Central de la República Argentina (BCRA), o acordo de 2009 com a China era inflexível, permitindo poucos usos aos recursos, ressaltando que não havia a permissão para livre conversibilidade do RMB para outras moedas de uso mais corrente (BCRA, 2014). Desse modo, tais valores não poderiam ser utilizados no caso de problemas de liquidez, o que era de interesse especial argentino, pois o país enfrentava, desde o início da década de 2000, dificuldades para acessar o mercado financeiro internacional devido a problemas no pagamento de sua dívida de anos anteriores.

Em julho de 2014, contudo, um novo acordo foi estabelecido, com a mesma cifra: 70 bilhóes de yuans. Dessa vez, entretanto, autorizaram-se usos que náo estavam previstos antes. O objetivo da tratativa, segundo BCRA (2014, p. 1, tradução nossa), foi não só "facilitar os investimentos na moeda do país provedor dos fundos", mas também "fortalecer o nível das reservas internacionais da parte que solicitar o desembolso". Diante das novas condiçóes e de uma situação financeira de crise, a Argentina acionou o acordo em 2014, usando US\$ 2,7 bilhóes dos recursos à disposição. Em setembro de 2015, atingiu-se o montante integral, de US\$ 11 bilhóes. Esse volume de recursos chineses 
representou, nas reservas internacionais argentinas, cerca de 35\% do total (Brenta e Larralde, 2018). Em 2014, a Argentina, ao estabelecer o acordo com a China, destacou a possibilidade de o yuan poder ser convertido livremente em outras moedas (op. cit.), o que de fato ocorreu, a fim de atender à necessidade de suplementar as reservas argentinas em dólares (BCRA, 2015).

Diante desse cenário, a China tornou-se para a Argentina seu emprestador de última instância (Stanley, 2019), o que, considerando as dificuldades de acesso do país ao mercado financeiro internacional, permitiu-o postergar acordos de ajuda com outras instituiçóes, como o FMI - acordo que, em 2015, findados os recursos chineses, e diante da contínua deterioração de sua situação financeira, a Argentina teve que fazer.

Se, por um lado, a utilização do acordo não contribuiu muito para a internacionalização do RMB - uma vez que os recursos não foram destinados para as reservas ou para o comércio e investimentos bilaterais -, por outro, ajudou a elevar a China como alternativa financeira viável em momentos de crise.

Em 2017, o BSA com a China foi renovado para mais três anos. Segundo BCRA (2017, tradução nossa), "o novo acordo seguirá afiançando a relação entre ambos os bancos centrais e fomentando o fortalecimento das condições financeiras para promover o desenvolvimento econômico e comercial em ambos os países". Durante a cúpula do Grupo dos Vinte (G20) de 2018 em Buenos Aires, acordou-se uma ampliação suplementar do swap de 70 bilhóes para 130 bilhóes de yuans (cerca US\$ 19 bilhôes), porém adicionou-se uma cláusula condicionante: a contrataçấo de um acordo stand-by, preventivo, com o FMI de US\$ 50 bilhôes a ser solicitado pela Argentina em caso de ativação do BSA. Com a suplementaçáo de valores, a linha de swap passou a equivaler, naquele momento, a mais de um ano de importaçóes provenientes da China ${ }^{16}$ e a mais de um terço das reservas argentinas, ${ }^{17}$ motivo pelo qual optou-se por vincular o uso dos recursos a um acordo com o FMI. Embora tal vinculação tenha atuado para oferecer mais garantias à China, foi o entâo chefe do BCRA, Federico Sturzenegger, que teria exigido a inclusão do ponto no acordo, ${ }^{18}$ possivelmente para sinalizar ao mercado que a Argentina usaria os recursos com responsabilidade. Nenhum outro BSA da China, à exceção dos acordos estabelecidos via CMI e CMIM, havia sido vinculado ao FMI.

16. De acordo com dados do Trade Map, para a Argentina, em 2017, as importações provenientes da China contabilizaram cerca de US\$12,3 bilhões, enquanto o novo valor do acordo de swap subiu para US\$ 19 bilhões. Disponível em: <https://www.trademap.org/Bilateral_TS.aspx>.

17. Em novembro de 2018 , segundo dados do FMI, as reservas argentinas eram de cerca de US $\$ 45$ bilhões. Disponível em: $<$ https://bit.ly/37Zlc1H>.

18. Disponível em: <http://bit.ly/3uxNUSe>. 
Tal exigência foi retirada quando se promoveu a renovação do acordo em agosto de 2020 por mais três anos (BCRA, 2020). Com a incorporação dos valores suplementares de 2018, os recursos do novo BSA totalizaram 130 bilhóes de yuans (US\$ 19 bilhóes). Segundo BCRA (2020, tradução nossa), a renovação dos acordos "contribui para promover o fortalecimento das condiçóes financeiras com a finalidade de prover suporte ao comércio e aos investimentos entre ambos os países, criar maior estabilidade financeira e fortalecer a relação entre ambos os bancos centrais". Desse modo, o acordo de 2020 retomou a flexibilidade de utilização dos recursos de swap que havia sido perdida com a vinculação ao FMI em 2018 - motivo pelo qual, levando-se em consideração a relação problemática que a Argentina tem com o fundo, dificilmente o acordo suplementar com a China seria acionado.

Essa experiência de BSA entre China e Argentina mostra que o acordo se tornou uma opção viável, para a Argentina, de acessar recursos em momentos de crise, o que foi possível devido à inclusão, a partir de 2014, de mais formas pelas quais o swap poderia ser acionado - não só a utilização para o comércio exterior e investimentos bilaterais, mas também para situaçóes de crise de liquidez. Interpreta-se que a motivação da China ao celebrar o BSA com o país tenha sido ofensiva, pois visou, como é citado em todos os BSAs (BCRA, 2009; 2014; 2017; 2020), incentivar o uso do RMB para o comércio e investimento. Mesmo a adição, desde 2014, da possibilidade de utilizaçâo dos recursos para a crise de liquidez náo pode ser considerada defensiva, pois náo esteve atrelada a contextos globais ou regionais de crise que pudessem afetar a China, de modo que o que se produziu com tal inclusão foi a promoção do poder financeiro do país enquanto alternativa aos mercados globais, cumprindo o acordo, sendo mais uma função financeira que monetária. No entanto, o acordo mostrou limites se pensado como forma de internacionalização do RMB.

\subsection{Brasil}

Brasil e China restabeleceram suas relações diplomáticas em 1974, dentro de um cenário de universalização e multilateralização de suas políticas externas, tendo sido celebrado em 1978 o primeiro acordo de comércio entre os países (Sousa, 2016). Foi a partir da década de 2000, contudo, que as relaçóes entre eles ganharam maior volume, tanto em termos econômicos como em termos políticos. Em 2003, a China ultrapassou o Japão como principal parceiro do Brasil na Ásia, e em 2009 ultrapassou os Estados Unidos, passando a ser a maior parceira comercial brasileira.

O gráfico 2 é ilustrativo do incremento comercial entre os dois países e realça o saldo positivo que o Brasil vem acumulando nas últimas décadas, tendo a China se tornado o principal mercado para a soja, o minério de ferro e o 
petróleo brasileiro. Já a pauta chinesa para o Brasil é focada na venda de produtos manufaturados diversos.

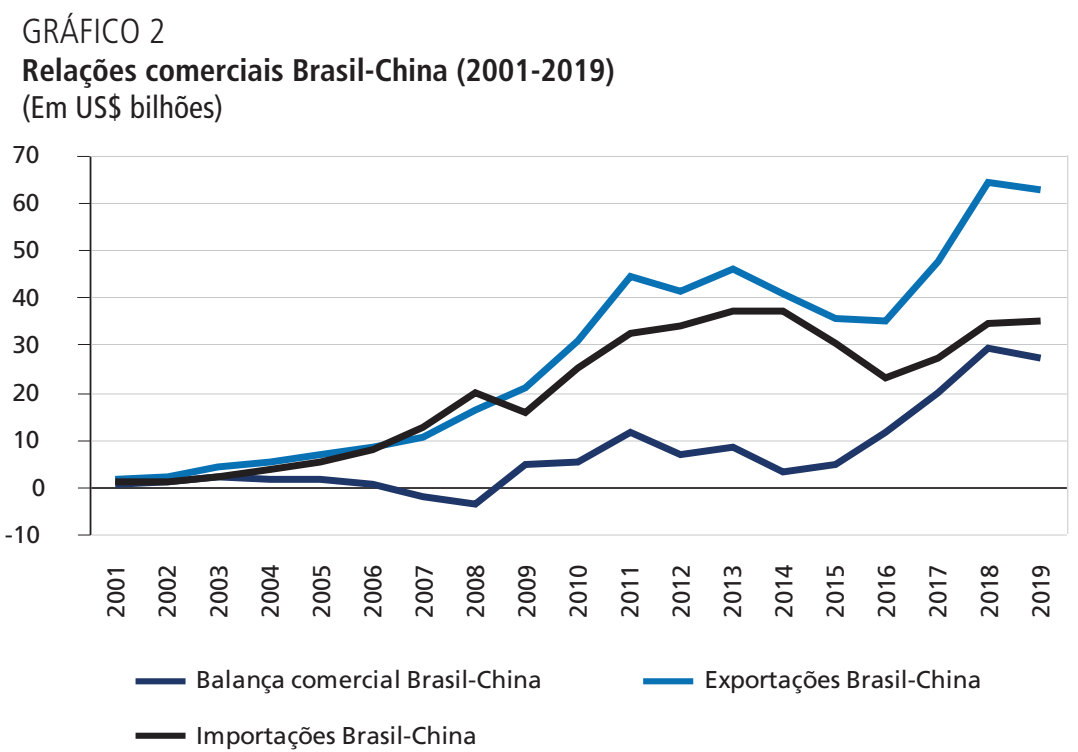

Fonte: Trade Map. Disponível em: <https://www.trademap.org/Bilateral_TS.aspx>.

Elaboração dos autores.

Politicamente, os países se aproximaram mais na década de 2000, destacando-se: em 2004, a constituição da Comissão Sino-Brasileira de Alto Nível de Concertação e Cooperação; em 2009, a primeira realização de cúpula do agrupamento Bric (acrônimo para Brasil, Rússia, Índia e China); em 2012, a constituição do Diálogo Estratégico Global; em 2014, a evolução da institucionalidade do Brics (acrônimo para Brasil, Rússia, Índia, China e África do Sul) com a constituição do Novo Banco de Desenvolvimento (NBD) e do Arranjo Contingente de Reservas (ACR); em 2015, o estabelecimento do Plano de Ação Global Conjunta entre Brasil e China; entre outros (Sousa, 2016).

A própria presença econômica da China também evoluiu do comércio para os investimentos e as finanças. Considerando o período de 2005 a 2019, Gallagher e Myers (2020) afirmam que o Brasil foi o segundo país da região a receber mais financiamentos chineses, contabilizando-se um total de US\$28,9 bilhóes. Já Schutte (2020) destaca em especial a partir de 2010, os crescentes investimentos no país, com destaque para os setores energético, manufatureiro e de commodities.

Foi nesse quadro de aprofundamento das relações que os países estabeleceram ainda em 2013 um BSA. Para Klein e Martins (2019), já havia uma frutífera cooperação financeira entre Brasil e China desde 2008 no âmbito do G20 e do 
Brics, sendo que ambos os países já tinham externado a vontade de incentivar as moedas locais nas transaçôes bilaterais. Em março de 2013, o BSA foi fechado, segundo a Resolução no 4.200 do Banco Central do Brasil (BCB) ${ }^{19}$ no valor de R \$ 60 bilhōes (cerca de US\$ 30 bilhōes), com vigência de três anos, prorrogável.

$\mathrm{O}$ objetivo de tal acordo, segundo as autoridades envolvidas, foi facilitar o comércio bilateral e aprofundar a cooperação monetária e financeira entre os países. ${ }^{20}$ Como revelou Alexandre Tombini, entáo presidente do BCB, o acordo foi "um passo importante no estreitamento das relações Brasil-China", ressaltando-se o objetivo de "facilitar o comércio entre os dois países independentemente da situação econômica internacional” (Brasil..., 2013).

Todavia, não foram realizadas operaçóes cambiais no BSA. Alguns fatores podem ser apontados como explicativos. O primeiro, levantado por Klein e Martins (2019), é o fato de o Brasil não ter tido problema de liquidez que afetasse o comércio bilateral com a China. As autoras adicionalmente destacam que, durante a vigência do acordo, os investimentos chineses cresceram no Brasil, contribuindo positivamente para a situação externa da economia.

Ao fim do acordo em 2016, não houve prorrogação. Importante notar que nesse momento já vigorava no âmbito do Brics o ACR. Tal acordo, ainda existente, tem como função oferecer recursos aos países do Brics em momentos de crise de liquidez. A esse fato, e corroborando os argumentos citados, acrescenta-se que, segundo comentou Yu Yong, entâo conselheiro econômico e comercial do Consulado-Geral da China em São Paulo, os empresários brasileiros não têm tido problemas para acessar dólares, de forma que não há impedimento, considerando tal motivo, para a realizaçáo do comércio e de investimentos com a China. Renovar o acordo teria o custo de manter recursos paralisados, tanto do lado brasileiro como do lado chinês, sendo que não havia a probabilidade de que fosse necessário usá-los. ${ }^{21}$

Assim, a experiência do BSA entre Brasil e China mostra que, considerando que a função principal foi resguardar o comércio bilateral, na ausência de problemas de acesso à moeda estrangeira (dólar), não houve necessidade de acionar o acordo. Embora a tratativa possa ter servido como uma forma de prover um quadro bilateral para dar maior segurança e garantia ao comércio exterior, como concluem Klein e Martins (2019, p. 48), no caso do Brasil, o acordo pode ser interpretado como "um ato político muito mais simbólico do que realmente prático".

\footnotetext{
19. Disponivel em: <https://bit.ly/3sUVmFB>.

20. Disponivel em: <https://bit.ly/385rzSx>.

21. Em 14 de junho de 2018, ocorreu, na Universidade de São Paulo (USP), o evento Rl em Debate: Fator China. Em uma das mesas, em que um dos autores deste artigo participou como palestrante junto ao conselheiro chinês, este comentou com todo o público o que aqui expressamos. Mais informações sobre o evento disponíveis em: <https:// cutt.ly/wk6KFwa>.
} 
De toda forma, interpreta-se que o objetivo do acordo chinês se mostrou ofensivo, visando à internacionalização do $\mathrm{RMB}$ - e, portanto, aspectos mais monetários que financeiros -, mas a não utilização e a não renovação do swap sinalizaram que com o Brasil o BSA foi, na prática, um mecanismo ineficiente para a operação do financial statecraft. O principal motivo para tal, como se pode concluir das informaçōes sobre o caso, e com base na literatura que analisamos, é que não houve demanda de RMB por parte dos operadores brasileiros para o comércio com a China. Prevaleceu-se, assim, a inércia da utilização de dólares para as trocas bilaterais, em meio a um cenário em que o RMB ainda mantém baixa conversibilidade. Yu Yong, conselheiro do Consulado-Geral da China em São Paulo, já citado, confirmou que não havia interesse do empresariado brasileiro em usar a moeda. ${ }^{22}$

\subsection{Chile}

O Chile foi o primeiro país da América do Sul a restabelecer relaçôes com a China em 1970 (Guilisasti, 2006). Todavia, até 1990, as relaçôes bilaterais não avançaram significativamente em termos econômicos (Gutiérrez e Cesarin, 2015). A partir da década de 2000, entretanto, como mostra o gráfico 3, o comércio exterior entre os países teve um incremento significativo, sendo que em 2007 a China tornou-se o maior destino para as exportaçóes chilenas, ultrapassando os Estados Unidos.

GRÁFICO 3

Relações comerciais Chile-China (2001-2019)

(Em US\$ bilhões)

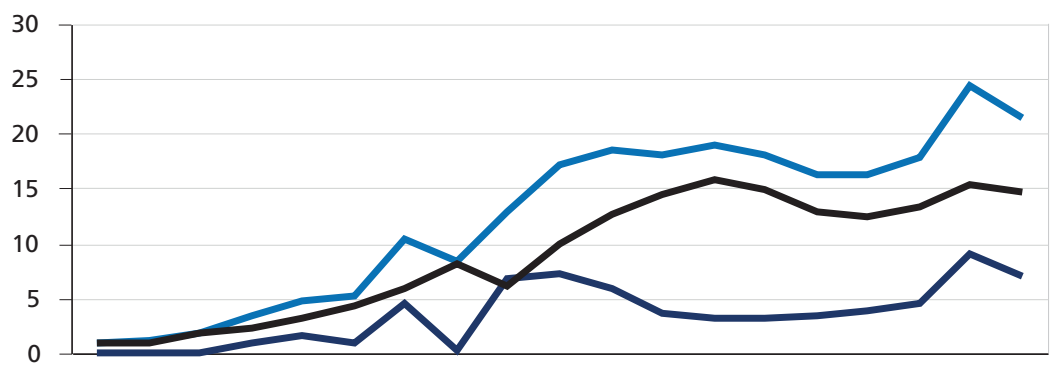

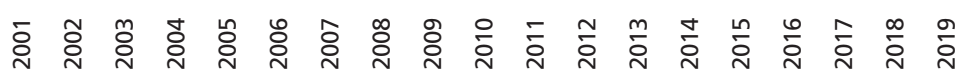

_ Balança comercial Chile-China

Exportações Chile-China

- Importações Chile-China

Fonte: Trade Map. Disponível em: <https://www.trademap.org/Bilateral_TS.aspx>.

Elaboração dos autores.

22. Mais informações sobre o evento disponíveis em: <https://cutt.ly/wk6KFwa>. 
Enquanto as exportaçốes chilenas para a China estão focadas no cobre, as vendas chinesas ao país concentram-se em manufaturados diversos - mesmo assim, o balanço comercial tem sido favorável ao Chile. Destaque deve ser dado à assinatura, em 2005, de um acordo de livre comércio entre os países. Gutiérrez e Cesarin (2015, p. 134, tradução nossa) argumentam que a maior aproximação com a China produzida nesses marcos refere-se à estratégia do regionalismo aberto adotada pelo Chile, na qual se entende

que o modelo de desenvolvimento chileno, baseado no dinamismo das exportaçóes e na abertura aos fluxos financeiros internacionais, necessitava de liberalização comercial concertada e a negociação de disciplinas econômicas com seus principais interlocutores na economia internacional.

Ao passo que aumentou a importância econômica da China para o Chile, politicamente, os países também aprofundaram as relaçóes. Em 2012, as interaçóes bilaterais foram elevadas ao patamar de parceria estratégica, refletindo o amadurecimento das relaçóes (Song, 2015). Em 2016, evoluiu-se para uma parceria estratégica abrangente, e em 2018 o Chile assinou o termo de cooperação para aderir ao BRI na expectativa de que isso pudesse atrair mais investimentos chineses.

É nesse quadro de aproximação que os países celebraram um BSA em 2015. Segundo BCCh (2015, p. 68, tradução nossa), o objetivo do acordo era "propiciar condiçóes que facilitem o uso do renminbi (RMB) no Chile". O acordo teria validade de três anos, prorrogável. O valor estimado foi de 22 bilhóes de yuans (cerca de US\$ 3,6 bilhôes), e o foco de utilização dos recursos, de acordo com BCCh (idem, ibidem), seriam os investimentos bilaterais e o comércio.

O BSA, contudo, não foi acionado. Do mesmo modo que o Brasil, o país não passou por dificuldades que pudessem atrapalhar o comércio e os investimentos bilaterais. Entretanto, mesmo sem haver a utilização, o acordo foi prorrogado ao fim do seu primeiro termo. Em julho de 2020, os países concordaram em realizar uma expansão do BSA tanto nos valores, passando de 22 bilhōes para 50 bilhóes de yuans (cerca de US\$ 7,1 bilhôes), como na utilizaçáo - além de apoiar o comércio e investimentos bilaterais, os recursos poderão também ser utilizados para manter a estabilidade nos mercados financeiros em casos de problema de liquidez. O Banco Central do Chile (BCCh) deixou claro que "a ampliação do acordo bilateral foi realizada com finalidade de precauçâo" (tradução nossa) ${ }^{23} \mathrm{e}$ reflete o aprofundamento da cooperação entre os países.

Assim, o que a experiência do acordo com o Chile indica, em especial considerando-se sua renovação e expansão com novas condiçôes de uso, é que o país 
vê a China como origem de ajuda financeira em caso de necessidade, preferindo-se de tal feita manter o acordo mesmo que não tenha sido utilizado nos últimos cinco anos. Embora o objetivo inicial de promover a utilização do RMB por meio da tratativa não tenha sido alcançado pela China, havendo, portanto, ineficiência do financial statecraft considerando esse aspecto monetário, a continuidade do swap, do lado financeiro, assinala haver algum potencial. Em termos de motivação, considera-se que os BSAs com o Chile foram vistos como um financial statecraft de natureza ofensiva, dado o interesse na internacionalizaçáo do RMB. Mesmo a extensão das condiçôes do acordo - para permitir-se a utilização para problemas de liquidez, em 2020 - também pode ser considerada ofensiva, pois não visou à defesa da estabilidade da economia chinesa, mas sim apresentar o país como alternativa financeira ao mercado, de maneira que, ao aspecto monetário, somou-se o financeiro na realização desse BSA.

\subsection{Suriname}

Até 1975 , o Suriname foi considerado território holandês. Só após o encerramento desse vínculo que foram estabelecidas relaçóes diplomáticas com a China, em $1976 .{ }^{24}$ Romero $(2011$, p. 1) destaca que só a partir da década de 1990, todavia, que as relaçoóes entre os países começaram a se intensificar, destacando que, embora "seja difícil conseguir números precisos, acredita-se que a China tenha emergido como o principal fornecedor de ajuda ao Suriname" nesta última década.

Os dados no gráfico 4 mostram que o comércio exterior tem sido crescente, sendo que o Suriname compra produtos manufaturados chineses diversos e tem como principais produtos de exportação para a China madeiras e pescados. O país tornou-se em 2019 o sexto destino das exportaçóes surinamesas e a quarta origem das importaçóes do país; a balança comercial, contudo, tem se revelado deficitária, como mostra o gráfico 4.

Apesar dos deficit, a China, segundo Koop (2020), se apresenta como importante investidora e financiadora na economia do Suriname, destacando-se por impor termos melhores que os tradicionais emprestadores internacionais, em especial considerando-se que o país tem sido mal avaliado por agências de rating. ${ }^{25}$ Com a intensificação das relações econômicas, os países também se aproximaram politicamente - em novembro de 2019, foi reforçada a parceria estratégica, estabelecida em 2018, e o Suriname aderiu ao BRI visando atrair mais investimentos chineses. ${ }^{26}$

24. Disponível em: <http://sr.china-embassy.org/eng/sbgxyw/t1619769.htm>.

25. Em janeiro de 2020, a agência Fitch Ratings rebaixou a nota do país de B- para CCC.

26. Disponível em: <http://portuguese.xinhuanet.com/2019-11/28/c_138589590.htm>. 


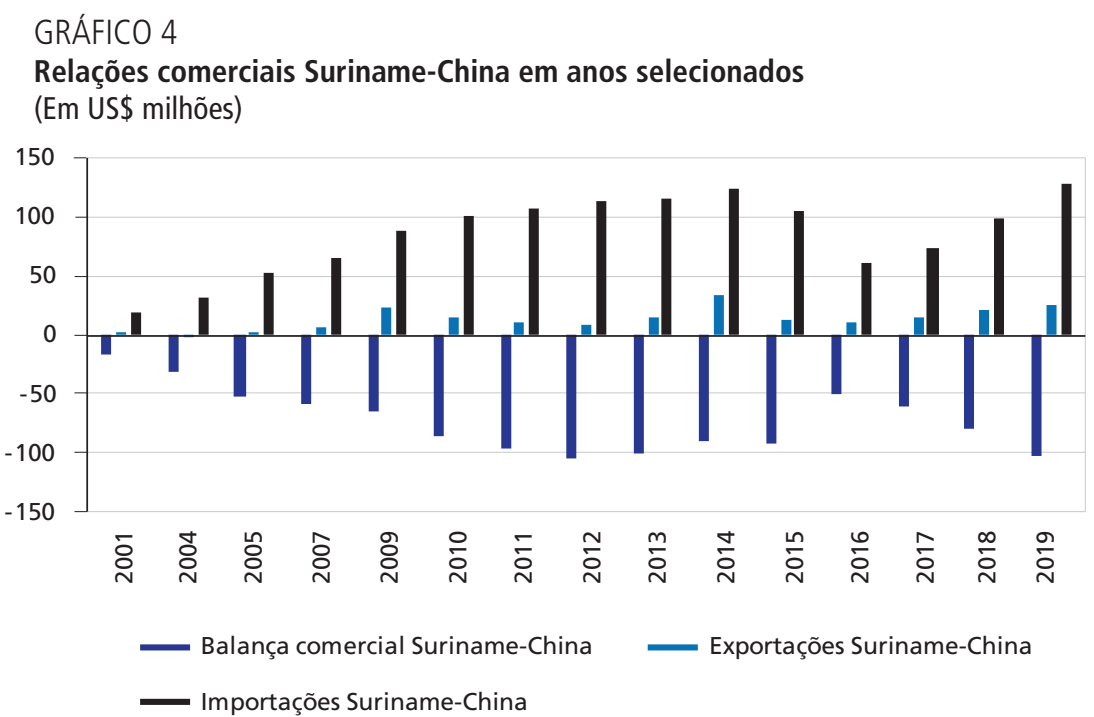

Fonte: Trade Map. Disponível em: <https://www.trademap.org/Bilateral_TS.aspx>.

Elaboração dos autores.

Nesse contexto de ampliação das relações, processou-se, em março de 2015, a assinatura do primeiro BSA de 1 bilhão de yuans (cerca de US\$ 160 milhóes) entre o Banco Central do Suriname (Centrale Bank van Suriname - CBvS) e o PBOC. ${ }^{27}$ Com prazo de três anos, prorrogável, o acordo teve a finalidade de fomentar a cooperação financeira e sustentar o crescimento das relaçôes comerciais e de investimentos entre os países. Ressalta-se que os recursos também ficaram disponíveis "para o propósito de estabilizar a paridade de poder de compra das respectivas moedas e através desse meio dar suporte à estabilidade financeira no país e na região do respectivo banco central" (tradução nossa). ${ }^{28}$ Tal acordo foi prorrogado em 2019 (Swap..., 2020).

O Suriname, contudo, não acionou o BSA, apesar da situação econômica ruim. Nas palavras do novo presidente Chan Santokhi: "Nosso país está em sérias dificuldades financeiras. O Tesouro está vazio, há escassez de moedas estrangeiras e uma dívida disparada paira sobre nossas cabeças" (tradução nossa). ${ }^{29}$ Diante desse cenário, o país vem discutindo a possibilidade de utilizar o BSA para garantir as importaçóes de produtos chineses (Swap..., 2020). A indicação de acionamento do BSA, de fato, daria a flexibilidade ao país caribenho de arcar com as transaçóes correntes com a China. Basta observar o volume mobilizado pelo acordo e o deficit com o país. Isso não garantiria, porém, o deficit total da balança

27. Disponível em: <http://sr.china-embassy.org/eng/sbgxyw/t1247076.htm>.

28. Disponivel em: <https://bit.ly/37TFnPl>.

29. Disponível em: <https://caricom.org/suriname-chan-santokhi-sworn-is-as-new-president-of-suriname/>. 
comercial. ${ }^{30}$ Contudo, até o momento em que escrevemos, agosto de 2020, o acordo não foi acionado.

Sob uma análise do financial statecraft, interpreta-se que a China ofertou o BSA visando a motivos ofensivos - a internacionalização do RMB e estabelecer para si um papel ativo como opção financeira em momentos de crise. $\mathrm{O}$ acordo tem o potencial de servir, assim, tanto a aspectos monetários como a aspectos financeiros, com destaque para este último, que vem sendo discutido enquanto possibilidade no momento. A renovação do acordo, proferida em 2018, bem como as discussóes vigentes sobre a possível utilização indicam, dessa maneira, como no caso do Chile e da Argentina, que o país vê a China como alternativa financeira para momentos de vulnerabilidade, sendo que esse aspecto do acordo - o financeiro - aparece como mais promissor que o aspecto monetário.

\section{CONSIDERAÇÕES FINAIS}

Os acordos bilaterais de swap cambial se mostram como importante ferramenta para prover liquidez em momentos de crise. Países com potencial ofertante têm se utilizado desse instrumento sobretudo em momentos de instabilidade dos mercados globais. A crise de 2008 é um exemplo claro, quando tanto Estados Unidos como China protagonizaram a oferta de recursos. Contudo, findado o momento agudo da crise, enquanto as linhas de swaps de bancos centrais de países desenvolvidos se retraíram, a China continuou a expandir as tratativas.

Argumentamos que esse movimento chinês faz parte de um conjunto de estratégias que na literatura recebeu o nome de financial statecraft, por meio do qual se busca ampliar e consolidar a força financeira e monetária do país. Assinalou-se que, a partir da crise de 2008, a China passou a usar os BSAs com motivação defensiva e também ofensiva na economia política internacional, visando a aspectos como a internacionalização do $R M B$, incentivando o uso da moeda para o comércio e investimentos bilaterais, e o atendimento a objetivos específicos de política externa, como o BRI. Com a América Latina, foram realizados acordos com Argentina, Brasil, Chile e Suriname.

A análise de tais casos mostrou que as tratativas foram celebradas em um contexto de crescente aumento da importância econômica da China para os países. Os acordos teriam visado primeiramente à internacionalização do RMB e, portanto, o aspecto monetário do financial statecraft. Posteriormente, entretanto, os BSAs avançaram também em direção ao atendimento de aspectos financeiros, dado que, à exceção do Brasil (com o qual não houve renovação do BSA), a possibilidade de utilização dos recursos expandiu-se para o oferecimento

30. Disponivel em: <https://statistics-suriname.org/en/trade-statistics-2/>. 
de liquidez: no acordo com a Argentina, em 2014; no acordo celebrado com o Suriname, em 2015; e na renovação celebrada com o Chile, em 2020. A utilização do acordo pela Argentina devido a problemas de liquidez em 2014-2015, além do fato de Suriname e Chile manterem, mesmo sem utilizar, os BSAs contemplando tal possibilidade de uso, evidenciou que a China é vista como uma alternativa financeira para os países em momentos de crise. Desse modo, considerando os BSAs como instrumentos de financial statecraft voltados ao aspecto financeiro, não é possível que afirmemos que há ineficiência chinesa.

Contudo, como destacamos no caso do Brasil, quando o acordo visa apenas ao aspecto monetário, na ausência de problemas de liquidez para as trocas bilaterais, e considerando que há inércia da utilização do dólar no SMI e baixa conversibilidade do RMB, os BSAs não se mostram efetivos. Desse modo, os acordos de swap apresentam limites se pensados enquanto estratégia direta para a internacionalização do RMB, ou mesmo como meio de substituir uma terceira moeda por moedas locais para o comércio e investimentos. Há, porém, indicaçôes que podem prosperar como forma alternativa aos tradicionais emprestadores internacionais.

\section{REFERÊNCIAS}

ARMIJO, L. E.; KATADA, S. N. Theorizing the financial statecraft of emerging powers. New Political Economy, v. 20, n. 1, p. 42-62, 2015.

BCCH - BANCO CENTRAL DE CHILE. Memoria anual 2015. Santiago: BCCh, 2015. Disponível em: <https://www.bcentral.cl/ documents/33528/133457/bcch_archivo_161212_es.pdf/e859fa3c-4f66-9d1c5e3c-f2172ebaa5e4?t=1573273886800 >. Acesso em: 18 jul. 2020.

BCRA-BANCO CENTRAL DE LA REPÚBLICA ARGENTINA. Comunicado no 49465. Buenos Aires: BCRA, 15 abr. 2009. Disponível em: <http://www.bcra. gov.ar/pdfs/comytexord/p49465.pdf>. Acesso em: 27 jul. 2020.

. Comunicado no 50464. Buenos Aires: BCRA, 30 oct. 2014. Disponível em: $<$ http://www.bcra.gov.ar/pdfs/comytexord/P50464.pdfs. Acesso em: 15 jul. 2020.

. Se convertirán yuanes del swap con China por US\$ 3.100 millones.

Buenos Aires: BCRA, 16 dic. 2015. Disponível em: <http://www.bcra.gov.ar/Pdfs/ Prensa_comunicacion/Nota_Prensa_I_16-12-15.pdf>. Acesso em: 12 ago. 2020.

El Banco de la República Popular de China y el Banco Central de la República Argentina renovaron hoy su acuerdo bilateral de swap de monedas. Banco Central de la República Argentina, 18 jul. 2017. Disponível em: $<$ http://www.bcra.gov.ar/noticias/Renovacion_swap_china.asp>. Acesso em: 11 ago. 2020. 
New agreement with the People's Bank of China. Banco Central de la República Argentina, 6 ago. 2020. Disponível em: <http://www.bcra.gov.ar/ Noticias/nuevo-acuerdo-swap-banco-republica-popular-china-i.asp $>$. Acesso em: 8 ago. 2020.

BLANCHARD, J.-M. F. Political aspects of Chinese investment in Latin America. Revista Tempo do Mundo, v. 2, n. 2, p. 35-49, July 2016. Disponível em: $<$ https://www.ipea.gov.br/revistas/index.php/rtm/article/view/41/35>. Acesso em: 10 jun. 2020.

BRASIL e China fazem acordo de R\$ 60 bi para garantir comércio em crises. BBC News, 26 mar. 2013. Disponível em: <https://www.bbc.com/portuguese/ noticias/2013/03/130326_brics_brasil_china_swap_jp_ru>. Acesso em: 5 ago. 2020.

BRENTA, N.; LARRALDE, J. La internacionalización del renminbiy los acuerdos de intercambio de monedas entre Argentina y China, 2009-2018. Ciclos: en la Historia la Economía y la Sociedad, n. 51, p. 55-84, 2018. Disponível em: <https://ojs.econ. uba.ar/index.php/revistaCICLOS/article/view/1355>. Acesso em: 5 ago. 2020.

CARMO, M. 'ArgenChina': por que a China desbancou Brasil como maior parceiro comercial da Argentina. BBC News Brasil, 25 ago. 2020. Disponível em: <https://economia.uol.com.br/noticias/bbc/2020/08/25/argenchina-porque-a-china-desbancou-brasil-como-maior-parceiro-comercial-da-argentina. htm>. Acesso em: 28 ago. 2020.

CHINA'S renmimbi has become world's second most used currency in trade finance. MercoPress, 2 Nov. 2015. Disponível em: <http://bit.ly/37U4Ad4>. Acesso em: 9 ago. 2020.

COHEN, B. J. Renminbi internationalization: a conflict of statecrafts. London: Chatam House, 2017. (Research Paper).

CORREAA, G. F.; BARBOSA, P. H. B. Uma tentativa brasileira de entender o funcionamento do governo e do setor privado na China. In: BARBOSA, P. H. B. (Org.). Os desafios e oportunidades na relaçáo Brasil-Ásia na perspectiva de jovens diplomatas. Brasília: Funag, 2017. (Coleção Relaçóes Internacionais). Disponível em: <https://bit.ly/2MxYxU2>. Acesso em: 20 ago. 2020.

DENG, Y. China's struggle for status: the realignment of international relations. New York: Cambridge University Press, 2008.

DESTAIS, C. Central Bank currency swaps and the International Monetary System. Emerging Markets Finance and Trade, v. 5, n. 10, p. 2253-2266, 2016. Disponível em: <https://www.tandfonline.com/doi/ full/10.1080/1540496X.2016.1185710>. Acesso em: 20 fev. 2020. 
DREZNER, D. W. Bad debts: assessing China's financial influence in great power politics. International Security, v. 34, n. 2, p. 7-45, 2009. Disponível em: <https://www.mitpressjournals.org/doi/10.1162/isec.2009.34.2.7>. Acesso em: 22 ago. 2020.

EICHENGREEN, B. Privilégio exorbitante: a ascensão e queda do dólar e o futuro do sistema monetário internacional. Tradução de Afonso Celso da Cunha Serra. Rio de Janeiro: Elsevier, 2011.

ELEISEGUI, P. Invasión silenciosa: China profundiza incursión en Argentina para controlar materias primas y sectores clave. IProUp, 20 sept. 2019. Disponível em: <http://bit.ly/3aYiooB>. Acesso em: 19 ago. 2020.

FERGUSON, N.; SCHULARICK, M. Chimerica and the global asset market boom. International Finance, v. 10, n. 3, p. 215-239, 2007.

FIESP - FEDERAÇÃO DAS INDÚSTRIAS DO ESTADO DE SÃO PAULO. Panorama da indústria de transformaçáo brasileira. 17. ed. São Paulo: Fiesp; Ciesp, 2019.

GALLAGHER, K. P.; MYERS, M. China-Latin America finance database. Washington: IAD, 2020. Disponível em: <https://www.thedialogue.org/map_ list/>. Acesso em: 18 ago. 2020.

GOWAN, P. A roleta global: uma aposta faustiana de Washington para a dominação do mundo. Rio de Janeiro: Record, 2003.

GUILISASTI, O. E. Las relaciones entre Chile y China: del simbolismo a la acción. Revista de Estudios Internacionales, v. 39, n. 154, jul.-sept. 2006.

GUTIÉRREZ, H.; CESARIN, S. Estudios subregionales China en el Cono Sur: regularidades, impactos y respuestas. In: SORIA, A. B; GARCIA, P. M. (Ed.). China en América Latina y el Caribe: escenarios estratégicos. San José: Flacso; CAF, 2015. KAJIMOTO, T. China-Japan sign three-year FX swap deal to strengthen financial stability, business activity. Reuters, 26 Oct. 2018. Disponível em: <http://reut. rs/388Q4yj>. Acesso em: 28 abr. 2020.

KAPLAN, S. B. Banking unconditionally: the political economy of Chinese finance in Latin America. Review of International Political Economy, v. 23, n. 4, p. 643-676, 2016. Disponível em: <https://doi.org/10.1080/09692290.20 16.1216005>. Acesso em: 10 jul. 2020.

KLEIN, I. L.; MARTINS, A. R. A. O contrato de swap sino-brasileiro: um mecanismo de incentivo do renminbi no Brasil? Oikos, v. 18, n. 2, p. 40-54, 2019. 
KOOP, J. China's Suriname: a case study on China's economic developing world policy. 2020. Dissertação (Mestrado) - Universidade de Leiden, Leiden, 2020. Disponível em: <http://hdl.handle.net/1887/134008>. Acesso em: 5 ago. 2020.

KROEBER, A. China's global currency: lever for financial reform. Beijing: Brookings-Tsinghua, 2013. (Monograph Series, n. 3).

MCDOWELL, D. The (ineffective) financial statecraft of China's bilateral swap agreements. Development and Change, v. 50, n. 1, p. 122-143, 2019. Disponível em: <https://onlinelibrary.wiley.com/doi/abs/10.1111/dech.12474>. Acesso em: 10 jul. 2020.

PARK, H.-S. China's RMB internationalization strategy: its rationales, state of play, prospects and implications. Cambridge, United States: Harvard University Press, 2016. (Working Paper Series, n. 63).

RÉPUBLIQUE FRANÇAISE. Ministère de l'Économie et des Finances. The global network of central bank swap lines. Paris: MEF, 2018. (Trésor-Economics, n. 231). Disponível em: <https://bit.ly/3q01R87>. Acesso em: 28 abr. 2020.

ROBERTS, C.; ARMIJO, L. E.; KATADA, S. N. The Brics and collective financial statecraft. New York: Oxford University Press, 2018.

RODRIGUES, B. S.; HENDLER, B. Investimento externo chinês na América Latina e no sudeste asiático: uma análise de escopo, valores e setores-alvo. Estudos Internacionais, v. 6, n. 3, p. 5-25, 2018.

ROMERO, S. China expande sua presença no Suriname. Estadáo, 15 abr. 2011. Disponível em: <https://internacional.estadao.com.br/noticias/geral,chinaexpande-sua-presenca-no-suriname-imp-,706502>. Acesso em: 29 jun. 2020.

RYAN, J. Geopolitical influences on the future of renminbi. Brussels: Egmont Institute, 2017. (Security Policy Brief, n. 82). Disponível em: <http://aei.pitt. edu/86887/1/SPB82.pdf>. Acesso em: 1 jul. 2020.

SAMAITA, K. Zimbabwe and China sign currency swap deal. Business Day, 15 Jan. 2020. Disponível em: <https://www.businesslive.co.za/bd/world/ africa/2020-01-15-zimbabwe-and-china-sign-currency-swap-deal/>. Acesso em: 28 abr. 2020.

SCHUTTE, G. R. Oásis para o capital - solo fértil para a "corrida de ouro": a dinâmica dos investimentos produtivos chineses no Brasil. São Paulo: Appris, 2020.

SONG, X. China y América Latina en un mundo en transformación: una visión desde China. In: SORIA, A. B.; GARCIA, P. M. (Ed.). China en América Latina y el Caribe: escenarios estratégicos. San José: Flacso; CAF, 2015. 
SOUSA, A. T. L. M. Relaçóes Brasil-China: interesses, questôes e resultados. 2016. Tese (Doutorado) - Programa de Pós-Graduação em Relaçôes Internacionais, Universidade Estadual Paulista Júlio de Mesquita Filho, São Paulo, 2016.

SOUSA, A. T. L. M.; FREITAS, W. D. The 2008 financial crisis and the renminbi internationalization. Conjuntura Internacional, v. 15, n. 2, 2018, p. 33-40. Disponível em: <https://doi.org/10.5752/P.1809-6182.2018v15.n2.p33>. Acesso em: 5 mar. 2021.

STANLEY, L. China's financing in Argentina. In: PETERS, E. D. (Ed.). China's financing in Latin America and the Caribbean. Ciudad Universitaria: Editora Unam, 2019. p. 193-208. Disponível em: <http://repositorio.cedes.org/ bitstream/123456789/4558/1/Stanley-\%20Chinas-financing.pdf>. Acesso em: 29 ago. 2020.

STEIL, B. Central Bank currency swaps tracker. Council on Foreign Relations, 5 Nov. 2019. Disponível em: <https://www.cfr.org/article/central-bank-currencyswaps-tracker>. Acesso em: 10 ago. 2020.

STRANGE, S. States and markets. New York: Bloomsbury, 1994.

SWAP deal met China moet importen veiligstellen. Dagblad Suriname, 23 Maa. 2020. Disponível em: <https://www.dbsuriname.com/2020/03/23/swap-dealmet-china-moet-importen-veiligstellen/>. Acesso em: 28 ago. 2020.

TOOZE, A. The forgotten history of the financial crisis: what the world should have learned in 2008. Foreign Affairs, Sept.-Oct. 2018. Disponível em: <https:// www.foreignaffairs.com/articles/world/2018-08-13/forgotten-history-financialcrisis>. Acesso em: 7 jul. 2020.

XIAOCHUAN, Z. Reform the international monetary system. Bis Review, n. 41, Mar. 2009. Disponível em: <https://www.bis.org/review/r090402c.pdf>. Acesso em: 15 jun. 2020.

XIN, Z. Yuan given to Russia under currency swap deal: Moscow has been grappling with a liquidity crisis amid plunging oil prices and Western sanctions. South China Morning Post, 6 Mar. 2016. Disponível em: <https://www.scmp. com/business/article/1919707/yuan-given-russia-under-currency-swap-deal $>$. Acesso em: 2 ago. 2020.

YELERY, A. China’s bilateral currency swaps agreements: recent trends. China Report, v. 52, n. 2, 2016. Disponível em: <http://journals.sagepub.com/doi/ abs/10.1177/0009445515627210>. Acesso em: 21 fev. 2020.

ZHANG, L.; TAO, K. The benefits and costs of renminbi internationalization. Tokyo: ABDI, 2014. (Working Paper, n. 481). 
ZHIMING, X.; XIAOKUN, L. China and South Korea in currency swap deal. China Daily, 13 Dec. 2008. Disponível em: <https://www.chinadaily.com.cn/ china/2008-12/13/content_7301572.htm>. Acesso em: 8 ago. 2020.

ZHITAO, L.; WENJIE, Z.; CHEUNG, Y.-W. China's bilateral currency swap lines. Hong Kong: GRU, 2016. (Working Paper, n. 13). Disponível em: <https:// www.cb.cityu.edu.hk/ef/doc/GRU/WPS/GRU\%232016-013\%20_YW.pdf>. Acesso em: 21 fev. 2020. 
